\title{
Mendeley as A Reference Management and Citation Generator for Academic Articles
}

\author{
Dewi Kusumaningsih \\ University of Veteran Bangun Nusantara Sukoharjo \\ Sukoharjo, Indonesia \\ dewikusumaningsih71@univetbantara.ac.id
}

\begin{abstract}
The purpose of this study is to analyze the problems that arise in using Mendeley as a reference management and citation generator for academic articles. It applied a Qualitative Approach by involving lecturers, teachers and students as the participants in a workshop. It adopted observation and interview as the data collecting techniques. The findings confirmed that participants were not used to attach multiple citations and were less skillful to categorize their referential documents on specific Mendeley folders, in addition to the lack of awareness to complete the metacognition of referential documents. The participants eventually experienced an improvement to operate the Mendeley software in order of procedures, including download the referential documents of the international journals and ebooks, categorize the referential documents on Mendeley folders, attach multiple citations in a particular topic on current article, and complete the metacognition of those referential documents.
\end{abstract}

Keywords: academic, articles internet, mendeley, reference technology,

\section{INTRODUCTION}

Mendeley is a referential system that relies on the internet connection in managing reference for academic journals. The system has been adopted by numerous national and international journals, including DOAJ, Scopus, Google Scholar, and Thompson; and potentially will undergo a massive growth of users in the future [1]. However, the introduction of this referential manager is still requiring more intensive socialization among academicians in Higher Education institutions due to the urgency of its usage for international reputable journals.

This article discusses the use of Mendeley by the lecturers, teachers and Indonesian Language and Literature Department students at University of Veteran Bangun Nusantara Sukoharjo. The author found out that participants faced several problems, including 1) unfamiliarity to the Mendeley usage among the participants, 2) installation of Mendeley plug-in on PC, 3) incapability in using Mendeley to arrange references for academic journals, 4) unfamiliarity to multiple citations for a particular topic of discussion, 5) difficulty in importing the referential documents into Mendeley listing system, and 6) lack of metacognition editing skill.

Several articles have discussed the similar topic previously [2], [3]. However, this article exclusively aims to counter the problems in using Mendeley as a reference management as well as citation generator and familiarize it among academicians. This effort represents an academic responsibility in leading the lecturers and students to the progress of competence in producing qualified academic outcomes.

Mendeley is a referential manager that relies on the online network to help researchers in generating the citations. It enables the users to explore and save particular references, add remarks, highlight particular parts of the documents, arrange references and bibliography consistently, and accommodate peer-to-peer research discussions among users efficiently. As a desktop-based application for reference management that relies on internet network [11], Mendeley provides a virtual social media for researchers to disseminate their academic products through the online server.

Mendeley which was acquired by Elsevier combines several elements, including Mendeley Desktop, referential management software, PDF, Mendeley Android, iOS, Mendeley Web and users' social media accounts for peer-topeer research discussions. It helps authors to categorize referential articles in PDF file format into a systematical order of folders. Its features enable users to read and highlight the particular parts of their referential articles. The integration of Mendeley with several basic software's, including Microsoft Word, Open Office and LaTex has generated an automatic function for citation and bibliography. It offers similar referential management systems as EndNote, Papers, and Zotero [3].

Mendeley was developed in November 2007 by three doctoral students in Germany. Its first version was introduced in August 2008 by Skype Former Founder, Warner Music Group Former Head for Digital Strategy, and academicians from University of Cambridge and John Hopkins. The software earned the sixth rank as the best social innovation among 100 top global companies at the Europe Start-Up of the Years 2009 and Techcrunch Europe. In 2013, Elsevier acquired Mendeley as an effective strategy to secure its global users and create a massive expansion in the research development.

Mendeley requires the standard operating systems, such as Windows, Macintosh, and Linux to manage the metacognition elements of the referential articles. It features data backup, synchronization, reference searching, tagging, filtering and file renaming. The authors may import the referential documents from external websites pinned on the browser bookmark, such as Google Scholar, Science Direct, ProQuest, and Springer before inserting citations in word processing programs, such as Microsoft Word, Openoffice.org, and Libre Office. Mendeley works through the BibTex format to synchronize the exported files. 
Meanwhile, Mendeley web provides more interactive features, including private and public group, newsfeed, comments and profile pages [4].

Citation functions to validate the originality of referential articles, from which the theoretical reviews and similar researches are adopted in the current article. It has been recognized as an academic etiquette for the author in producing academic records and as the protection for the previous author's intellectual rights to avoid plagiarism.

With an automatic citation feature, Mendeley enables users in attaching either single or multiple citations neatly. It also offers several options of bibliography format, including American Medical Association, American Political Science Association, and American Psychological Association $6^{\text {th }}$ edition.

The prevention of plagiarism may run through several endeavors by understanding various citation and bibliography formats. The authors must have a specific awareness about the citation and bibliography before publishing their academic articles [2].

An academic article emphasizes on the objectivity of a particular phenomenon, thus differs from the popular and fiction articles [10]. It contains systematical, logic and brief facts explored from numerous reviews that have been proved through numerous methods, including observation, laboratory experiments, and relevant literature review. Final paper, thesis, dissertation, proceeding, textbook, monograph and actual news events are some instances of the academic articles.

It uses scientific language style from the standard guidance, such as Pedoman Umum Ejaan Bahasa Indonesia - PUEBI (General Guidelines for Indonesian Language Spelling). Through this standard language guidance, the authors may refer to the use of standard diction, borrowing words, numbering format and punctuations [7], [8], [9], [10].

Academic articles put a detail attention to the use of effective sentences in conveying information to the readers. The effective sentences comprise of correspondence, conceptual units, frugality, logic, assertiveness, variation, parallelism, standard structure, and succinctness [8].

The unity of each paragraph in an article is also important in drawing out the main idea to produce an exposition.

\section{METHODS}

This article adopted a Qualitative Approach by involving the lecturers, teachers and Indonesian Language and Literature Department students that came from different personal backgrounds and various level of capability in operating computer programs

The data collecting techniques applied observation and interview to record the participants' awareness in using Mendeley as a reference management and citation generator. The first stage of observation aimed to check the participants' devices and ensure that they had installed the software. The participants were encouraged to form discussion groups based on their progress on the software installation process, thus the observation would proceed the next procedures efficiently. The problems in using Mendeley would become the main discussion, of which the author was responsible to help participants in accessing, inserting, installing and operating Mendeley desktop.

Most of the participants found problems in installing Mendeley desktop, accessing referential articles from Mendeley feeds, and importing referential articles to Mendeley tab. They requested a guidance in completing the metacognition information from the referential articles, reading the referential system, and picking up citation from those referential documents. The inquiry process was averagely established by the participants who had understood the basic operation of Mendeley as a referential manager.

This article deployed a Descriptive Method through a content analysis to explore the data in an detail discussion and generate solution for the problems [5]-[6].

\section{RESULTS AND DISCUSSION}

These findings highlight a brief description from the data analysis from 25 participants who had involved in the workshop. They basically had low to mid level of understanding in using Mendeley as an online referential manager. Some of the participants had installed the software, meanwhile some other had just downloaded it. The observation found out that the participants faced several problems in using the system, including:

1. Slow connection of installation due to insufficient Wi-Fi support for a mass use. To counter this problem, the author encouraged the participants who had successfully installed the software to guide the others in finishing their process. It was recommended for the participants to provide high specification of the devices to operate Mendeley.

2. Partial understanding about Mendeley operational procedures. To counter this problem, the participants were encouraged note the author's explanation and hold a regular practice of using Mendeley.

3. Failure of Mendeley integration for Microsoft Word plug-in. Some participants might have opened several windows of Microsoft Word documents before finishing Mendeley installation that caused incomplete synchronization between Mendeley and Microsoft Word system. The author suggested the participants to close all Microsoft Word documents before installing Mendeley.

4. Insufficient capability to secure referential documents on Mendeley folders. The author suggested the participants to pick up several referential documents, either from (a) private collections from PC folders, (b) online academic articles downloaded from Google Search Results, or (c) Mendeley online feeds from Elsevier. The participants then categorized those documents based on the topics by 
providing folders through Add Folder and Add File menu on Mendeley desktop.

5. Insufficient capability to attach multip le citations in a particular topic. Most of the participants had not recognized the use of multiple citations for a contextual discussion from some experts. The author recommended the participants to add another referential article after inserting single citation on the reference toolbar. The participants could also choose the optional citation styles, including AMA, IEEE, APA, and Harvard.

6. Confusion to pick up the whole referential documents from computer to Mendeley desktop. The author recommended the participants to categorize the documents in specific folders on their PC before importing them to Mendeley.

7. Unfamiliarity to collect the documents containing the similar topic of discussion into the specific Mendeley folders. The author advised the participants to make specific folders as reference packs on Mendeley desktop to categorize the similar documents in one folder.

8. Insufficient capability to complete the metacognition elements of the referential documents. The author explained that the participants could look at the third column of Mendeley desktop to find the details of each article and complete the information. The participants ought to be informed that the metacognition is the key definition of the documents' validity.

\section{CONCLUSION}

This article offers practical solutions through moduls and guidelines for the problem that arise in using Mendeley as an easy referential manager [2]-[4]. It suggests the participants in improving their competence and skills, thus they will be capable to comprehend and practice the technical guidelines of using Mendeley. The operation of this referential manager also requires sufficient computer specification and internet connection for efficient access.

\section{ACKNOWLEDGMENT}

Thank you to the Republic of Indonesia Ministry of Research and Higher Education for funding this research.

\section{REFERENCES}

[1] M. K. Hensley and M. K. Kern, "Citation management software: Features and Futures," Ref. User Serv. Q., 2011.

[2] P. Istiana, "Membuat Sitasi dan Daftar Pustaka," ResearchGate, no. May 2013, 2013.

[3] M. Sayuti and C. Puspasari, "MENGUASAI MENDELEY;", in Manajemen Pengutipan Referensi untuk Kaya Ilmiah, 2017.

[4] E. Kusmayadi, Pemanfaatan aplikasi mendeley dalam pengelolaan informasi. Bogor, 2014.

[5] R. Santosa, Metode Penelitian Kualitatif Kebahasaan, 1, April 2 ed. UNS Press, 2017.

[6] Sudaryanto, Metode dan Aneka Teknik Analisis Bahasa: Pengantar Penelitian Wahana Kebudayaan Secara Linguistis. Yogyakarta: Sanata Dharma University Press, 2015.

[7] Sugihastuti, Bahasa Laporan Penelitian. Yogyakarta: Pustaka Pelajar. 2000.

[8] SH. Wijayanti, Dkk., Bahasa Indonesia Penulisan dan Penyajian Karya Ilmiah. Jakarta:PT RajaGrafindo Persada

[9] D. Kusumaningsih, Terampil Berbahasa Indonesia. Yogyakarta: Andi

[10] Nurjamal, Dkk., Terampil Berbahasa. Bandung: Penerbit Alfabeta.

[11] Wikipedia. "Mendelay". $9 \quad 9 \quad$ September 2018. https://en.m.wikipedia.org/wiki/Mendeley 